
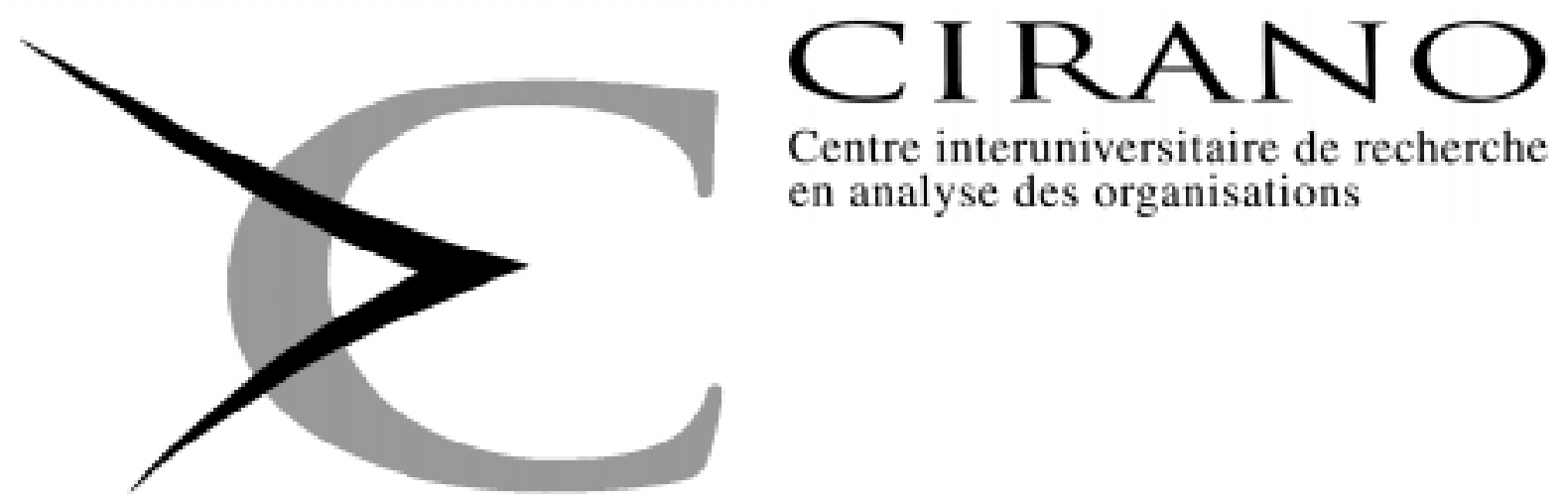

Centre interuniversitaire de recherche en analyse des organisations

Série Scientifique

Scientific Series

97s-14

Methods of Pay and

Earnings: A Longitudinal

Analysis

Daniel Parent 


\section{CIRANO}

Le CIRANO est une corporation privée à but non lucratif constituée en vertu de la Loi des compagnies du Québec. Le financement de son infrastructure et de ses activités de recherche provient des cotisations de ses organisations-membres, d'une subvention d'infrastructure du ministère de l'Industrie, du Commerce, de la Science et de la Technologie, de même que des subventions et mandats obtenus par ses équipes de recherche. La Série Scientifique est la réalisation d'une des missions que s'est données le CIRANO, soit de développer l'analyse scientifique des organisations et des comportements stratégiques.

CIRANO is a private non-profit organization incorporated under the Québec Companies Act. Its infrastructure and research activities are funded through fees paid by member organizations, an infrastructure grant from the Ministère de l'Industrie, du Commerce, de la Science et de la Technologie, and grants and research mandates obtained by its research teams. The Scientific Series fulfils one of the missions of CIRANO: to develop the scientific analysis of organizations and strategic behaviour.

\section{Les organisations-partenaires / The Partner Organizations}

•École des Hautes Études Commerciales

-École Polytechnique

-McGill University

-Université de Montréal

-Université du Québec à Montréal

-Université Laval

-MEQ

-MICST

-Avenor

-Banque Nationale du Canada

-Bell Québec

- Caisse de dépôt et de placement du Québec

-Fédération des caisses populaires Desjardins de Montréal et de l'Ouest-du-Québec

-Hydro-Québec

-Raymond, Chabot, Martin, Paré

-Société d'électrolyse et de chimie Alcan Ltée

-Téléglobe Canada

-Ville de Montréal

Ce document est publié dans l'intention de rendre accessibles les résultats préliminaires de la recherche effectuée au CIRANO, afin de susciter des échanges et des suggestions. Les idées et les opinions émises sont sous l'unique responsabilité des auteurs, et ne représentent pas nécessairement les positions du CIRANO ou de ses partenaires.

This paper presents preliminary research carried out at CIRANO and aims to encourage discussion and comment. The observations and viewpoints expressed are the sole responsibility of the authors. They do not necessarily represent positions of CIRANO or its partners.

ISSN 1198-8177 


\title{
Methods of Pay and Earnings: A Longitudinal Analysis*
}

\author{
Daniel Parent ${ }^{\dagger}$
}

\author{
Résumé / Abstract
}

\begin{abstract}
Cet article examine le lien entre les méthodes de rémunération, incluant les bonus et le métayage, et le niveau ainsi que la variance des revenus de travail. Les données utilisées proviennent du National Longitudinal Survey of Youth (1988-1990). Les résultats indiquent que les travailleurs payés à l'unité gagnent en moyenne davantage que les autres travailleurs, et ce résultat est robuste à l'estimation des premières différences. Par ailleurs, l'estimation d'un modèle simple représentant la structure de covariance des salaires montre que la majorité de la dispersion des salaires pour les travailleurs payés à l'unité est attribuable à la productivité non-observée de ces travailleurs.

In this paper, I investigate the relationship between methods of pay, including piece rates and bonuses, and the level and variance of wages using longitudinal data from the NLSY (1988-1990). Results using OLS and fixedeffects show that piece rate workers earn a premium compared to other workers while the positive effect of bonuses measured with OLS disappears when I use fixed-effects. Also, it is shown that the effect of piece rates is negatively related to the level of tenure, which suggests that rates may be cut as workers accumulate seniority. Finally, using minimum distance procedures to estimate a covariance model of wages, I am able to show that most of the variance for piece rate workers can be attributed to unobserved worker productivity, which is not the case for workers having pay for performance schemes.
\end{abstract}

Mots Clés : $\quad$ Méthodes de rémunération, niveau et dispersion des salaires

Keywords : $\quad$ Methods of pay, wage level, wage dispersion

JEL : J33

\footnotetext{
*Correspondence Address: Daniel Parent, CIRANO, 2020 University Street, 25th floor, Montréal, Qc, Canada H3A 2A5 Tel: (514) 985-4026 Fax: (514) 985-4039 e-mail: parentd@ cirano.umontreal.ca I wish to thank Bentley MacLeod for many discussions on this topicand seminar participants at the Princeton Lunch for comments on an early draft of this paper. Part of the work was done while I was visiting Princeton University. I wish to thank this institution for its hospitality.
}

† Université de Sherbrooke, C.R.D.E. and CIRANO 


\section{Introduction}

Over the last twenty years or so, a number of theoretical models have been developed to analyze the employment relationship, especially in terms of the appropriate way to structure the contracts so as to provide the correct incentives. Despite the rapid pace at which information economics has progressed, empirical investigations of the implications of these models (let alone direct testing of the models themselves) have been rather rare. The obvious reason for this state of affair is the lack of data. Recently though, a few empirical studies have emerged that use either firm-level data (see Baker, Gibbs and Holmstrom, 1994a,b) or across-firms data on a subset of the labor force such as executive officers (e.g. Gibbons, Murphy, 1992) . To the best of this author's knowledge, only Ewing (1996), Brown (1990, 1992) and Seiler (1984) have used large data sets that are more representative of the labor force. Ewing uses one wave of the National Longitudinal Survey of Youth to study the use and wage impact of pay-for-performance schemes while Brown and Seiler make use of the U.S. Bureau of Labor Statistics' Industry Wage Surveys to look at this issue. Case studies are no doubt a very valuable source of information for examining questions pertaining to so-called internal labor markets (Doeringer and Piore 1971). But, due to the nature of the data, such studies have to abstract from market forces. On the other hand, the data on CEO's usually contains a fair amount of detail allowing the study of incentive models whose empirical implications could not really be tested using survey-type data sets. The drawback, though, is that top management workers are but a small fraction of the labor force. In this paper, I make use of three straight waves from the National Longitudinal Survey of Youth (NLSY) for the years 1988 to 1990. Over that three year period, workers were asked if part of their labor earnings were based on job performance. They were also asked what form of incentive schemes was used by their employer. Thus, at the first level, we can examine the extent to which incentive pay is used in a relatively representative sample of young workers. It is generally believed that pay for performance schemes are seldom used, at least compared to promotions (e.g. see Baker, Jensen, and Murphy (1988) $)^{1}$. However, the data show that a non negligible fraction of workers earn at least part of their labor income through bonuses and/or piece rates.

The objective in this paper is to examine the impact of being paid

\footnotetext{
${ }^{1}$ Note that 1 am using the term "pay-for-performance" to refer to the method of pay (i.e.piece rate or bonus). The label is somewhat of a misnomer in that a contract specifying a fixed salary can provide just as much incentives to the worker to perform if the threat of employer-initiated separations is effective.
} 
either a piece rate or a bonus on the wage, controlling for unobserved worker productivity. Also of interest is the magnitude of the impact as workers accumulate tenure with their respective employers. Results using ordinary least-squares show that workers earning part (or all) of their income due to "explicit incentives" earn on average more than other workers paid hourly rates or salaries. This results holds for piece rate workers (but not for bonus workers) even when 1 use fixed-effects. In addition, the impact of being paid a piece rate is shown to be a negative function of tenure, while such an effect is non-existent for workers paid bonuses. This result is consistent with workers having their rates cut by the employers, although a selection effect by which good piece rate workers leave early in the employment relationship would also be consistent with this result. Finally, having three years of data allows me to estimate a simple covariance model of wages by type of contract. The results indicate that, as predicted in Lazear (1986), most of the unexplained variance of wages for piece rate workers can be attributed to unobserved worker productivity. The same cannot be said of workers paid either bonuses or salaries/hourly rates.

The paper is structured as follows. The next section reviews a few theoretical models which are the most useful in terms of their empirical implications, given the data at my disposal which I describe in the following section. Then I study the effects of pay-for-performance schemes on the level and the dispersion of labor earnings by exploiting the longitudinal structure of the data. I conclude in the final section by pointing out a few caveats to be kept in mind.

\section{Theoretical Considerations}

\subsection{Relationship between Piece Rates and Earnings}

Lazear's (1986) two-period model analyzes the conditions under which piece rate contracts are preferred to fixed salaries. He defines salaried workers as individual for whom

$$
w=g(E)
$$

where $\mathrm{E}$ is some measure of effort (e.g. hours worked). For piece rate workers,

$$
w=f(q)
$$

where $q$ is output. A crucial assumption in Lazear's model is the existence of a monitoring cost. Without such an assumption, no fixed salary 
jobs would exist. Let $\mathrm{C}$ be the monitoring cost, $\mathrm{R}$ the piece rate and $\mathrm{q}$ the output. For piece rate jobs, we have

$$
w=R q-C
$$

and for fixed salary jobs,

$$
w=E(q)
$$

It is assumed that people can work in other jobs at $\mathrm{w}^{*}$. If $E(q)>w^{*}$ and there are no piece rate firms, then all workers work at this firm. But this result is inefficient: those for whom $q<\mathrm{w}^{*}$ should take the alternative job. Separating them from the others causes expected output to increase. If both parties are equally uninformed as to the productivity of the worker, then separation can be achieved by putting everybody in the piece rate job for a period of time in order for both parties to learn q. After they learn q, those with $\mathrm{Rq}>\mathrm{w}^{*}$ stay in the piece rate job. With asymmetric information, less productive workers select themselves into the salary jobs. The firms know that they have attracted low ability workers and they pay accordingly. Thus, the mean earnings of piece rate workers should be higher than for salaried workers. Pencavel (1977), Seiler (1984), Brown (1992) and Ewing (1996) each have found evidence that piece rate workers are paid more than salaried workers. Also, since pay and productivity are more closely linked in the case of piece rate contracts, the variance of wages for piece rate workers should be greater than for other workers. Seiler (1984) found evidence from the Industry Wage Surveys that the wages of piece rate workers are indeed more dispersed than is the case for other workers. However, he interprets this finding as evidence that piece rate workers are paid compensating wage differentials for the increased risks they face.

\subsection{Intertemporal Strategic Behavior}

Piece rates can be negatively related to past output. Realizing this, workers depress this period's output in order to have a better rate in the next period (the so-called ratchet effect). Lazear argues that this strategic behavior can be undone by inflating the piece rate in the first period. Workers will respond with a higher effort level even though they anticipate that the employers will cut their rates in the second period. Thus, if Lazear's story is correct, we should see a stronger effect of piece rates on earnings early in the employment relationship. This prediction hinges completely on the assumption that workers can fully commit not to quit at the end of period one. Employers must be in a position

to exploit some ex post monopsony power. Otherwise, a competitive 
firm can attract workers whose rates have been decreased. This idea is formally developed in Kanemoto and MacLeod (1991) where they show that the existence of outside opportunities can eliminate the ratchet effect, even when workers incur mobility costs. In the context of a twoperiod model, firms compete for a fixed number of workers. Competition among firms thus reduces ex ante profits to zero. A cost $\mathrm{C}$ is borne by the workers each time they take on a job (mobility cost or cost of retraining). This cost captures the fact that once a worker is in a job, the firm has some monopsony power over that person. The firm then tries to exploit this power by lowering rates (or increasing sales targets) in the second period. Kanemoto and MacLeod show that for sufficiently low mobility costs, competition for what they call second-hand workers can eliminate the ratchet effect. Contrary to Lazear, they do not need perfect commitment to get efficient piece rate contracts.

Summarizing the different predictions stemming from the models just reviewed, we have: 1) more productive workers will choose piece rate jobs (Lazear (1986)). In other words, any measured positive relationship between piece rates and wages is attributed to self-selection on the part of workers. Thus, using fixed effect methods should result in the elimination of all positive effects; 2) since piece rate schemes gear the worker's compensation directly to output, the variance of wages should be larger for piece rate jobs than for salaried jobs and 3) Lazear's model predicts that the effect of piece rates should be stronger early in the employ-

ment relationship, while Kanemoto and MacLeod predict no such time decreasing pattern.

\section{The Data}

The National Longitudinal Survey of Youth data set surveyed 12,686 young males and females who were between the age of 14 and 21 in 1979. In 1988, 1989, and 1990, respondents were asked whether all or part of their earnings were based on job performance. They were also asked a few questions on their work environment. For instance, we know if the respondents were supervising other employees and whether they had received a promotion since the last interview. Unfortunately, we do not know the precise dollar amounts of incentive pay received by workers nor do we know the proportion of their earnings which is due to pay-for-performance. These represent significant data limitations which constrain the interpretation of our results.

The question pertaining to pay-for-performance is the following: "THE EARNINGS ON SOME JOBS ARE BASED ALL OR IN 
PART ON HOW A PERSON PERFORMS THE JOB (HAND CARD D). ON THIS CARD ARE SOME EXAMPLES OF EARNINGS THAT ARE BASED ON JOB PERFORMANCE. PLEASE TELL ME IF ANY OF THE EARNINGS ON YOUR JOB (ARE/WERE) BASED ON ANY OF THESE TYPES OF COMPENSATION. PLEASE DO NOT INCLUDE PROFIT SHARING OR EMPLOYEE STOCK PURCHASE PLANS.

1. PIECE RATES.

2. COMMISSIONS.

3. BONUSES (BASED ON JOB PERFORMANCE).

4. STOCK OPTIONS.

5. TIPS.

6. OTHER."

We should note that it is not possible to tell a priori whether the bonuses refer to amounts paid at the discretion of the employer when the latter subjectively considers that the performance of the employee is worthy of a cash reward, or whether they merely represent another form of piece rate. In the latter case, the employee gets a reward for achieving or surpassing some kind of quantitative target which can be objectively determined. ${ }^{2}$ Some summary statistics are presented in table 1.

Table 2 shows the total number of observations present in the unbalanced sample, by occupation and industry affiliations (1 digit level). We restrict the sample to individuals who were in the labor market on a full-time basis. The people who were considered as meeting that criterion were (i) those whose primary activity was either working full-time, on a temporary lay-off or looking actively for a job, (ii) those who had worked at least half the year since the last interview and who were working at least 20 hours per week. Individuals excluded from the sample are those who have been in the military at any time, the self-employed and all public sector employees. These restrictions leave us with 8,165 observations (3,847 workers).

Using the same format, tables 3 and 4 show the number of workers whose earnings were, at least in part, based explicitly on performance. Note that all those who declared having been paid by commissions are lumped together with piece rate workers. There were so few observations of workers earning tips or part of stock option plans that I simply ignore them henceforth and focus on bonuses and piece rates. Piece rates and/or bonuses are observed for $21 \%$ of the sample (1,732 observations). Of these, it should be noted that 188 observations represent workers

\footnotetext{
${ }^{2}$ See Baker, Gibbons and Murphy (1994) and MacLeod and Malcomson (1989) on the subject of implicit and explicit contracts.
} 
whose earnings depend on both piece rates and bonuses. In terms of percentages, both subsamples show that the occurrence of bonuses and piece rates is particularly concentrated in the manufacturing and wholesale and retail trade industries, in line with the proportion of the total sample coming from these two sectors. However, there seems to be significant differences between the two forms of incentive pay when we look at the occupations. For the piece rate subsample, nearly $63 \%$ of the workers are either salespersons, operatives or craftsmen. However, these three occupation categories include less than $35 \%$ of the workers paid bonuses. Bonuses seem to be most common among professional and technical workers, managers and administrators, and clerical workers. Of all those being paid bonuses, $54 \%$ of the work force is represented by these three occupational categories. Although it seems reasonable to think that many of the bonuses paid to managers are in effect another form of piece rates in which pay is based on the number of units sold or produced, this conjecture is not so obvious for professionals and clerical workers. Thus it appears that the bonuses reported in these data are, to a degree, a different form of incentive scheme.

Table 5 shows the same breakdown for the subsample consisting of workers who received promotions over the sample period. One interesting aspect of that table is its similarity with table 4 in terms of the occupational patterns. ${ }^{3}$ A casual glance at tables 4 and 5 suggests that bonuses based on job performance and promotions are correlated, which is not the case for piece rates. Given the problem that we have with the data on promotions, table 6 presents the same breakdown for workers whose responsibilities increased from one interview to the next. This variable and promotions are very highly correlated in the two years where the data on promotions seems reliable.

\section{Estimation and Results}

\subsection{Methods of Pay and the Effect of Earnings}

Consider the following log-wage equation:

$$
\begin{aligned}
\ln w_{i t} & =X_{i t} \beta+p_{i t} \delta_{1}+b_{i t} \delta_{2}+\eta_{i t} \\
\eta_{i t} & =\alpha_{i}+\epsilon_{i t}
\end{aligned}
$$

\footnotetext{
${ }^{3}$ Although the data on promotions covers the $1988-1990$ period, no promotions are reported in 1990. In fact, all workers's answers to this question are coded as "valid skips" (i.e. the question is irrelevant). This is hard to believe given that over 1,400 promotions are reported in 1988 and 1989.
} 
where $\mathrm{w}$ represents labor earnings per hour of worker $\mathrm{i}$ at time $\mathrm{t}, \mathrm{X}$ is a vector of controls ${ }^{4}, \mathrm{p}_{i t}$ is equal to one if worker i is paid a piece rate at time $\mathrm{t}$ and $\mathrm{b}_{i t}$ is a similar indicator for the presence of a bonus, $\alpha_{i}$ represents unobserved worker productivity, and $\epsilon_{i t}$ is an error term that is independently and identically distributed. Previous studies, such as Brown (1992), Seiler (1984) and Ewing (1996) have all found that piece rate workers earn more than either salaried workers or hourly paid workers. For comparison purposes, I first estimate equation (5) using OLS to determine whether the same empirical pattern is present in these data. It is not clear a priori what sign should be expected for $\delta_{2}$. If most of the bonuses paid have more in common with piece rates than with merit pay, then we should expect a similar effect. If instead these bonuses are more like merit pay cash rewards, then according to models such as the one in MacLeod and Malcomson (1989), there is no reason to expect workers paid bonuses to earn more on average compared to other workers.

According to Lazear (1986), the empirical regularities found in previous studies can be attributed to workers selecting the type of contract they prefer according to their productivity. More able workers will selfselect into piece rate jobs while other workers choose time rate jobs (or straight salaries). Thus, any measured positive effect of piece rate on earnings cannot be attributed to an incentive effect. In other words, switching all time rate workers to piece rate jobs would not cause an increase in productivity (and wages). In terms of equation (5), this means that $\mathrm{p}_{i t}$ is positively correlated with $\alpha_{i}$. Consequently, if the positive effect of piece rates on wages is due solely to a selection bias, then estimating (5) with fixed-effects should result in the estimated $\delta_{1}$ being close to zero. ${ }^{5}$ On the other hand, if piece rates (and bonuses) truly have an incentive effect, then the measured effects should not disappear once fixed-effects are used.

A second prediction from Lazear's model is that firms adjust rates upward in the first period of the employment relationship to provide sufficient incentives for workers to give the first-best level of effort, even if the workers know that employers cannot be prevented from behaving opportunistically in the second period by decreasing the rates once they know the productivity of their workers. If the bonus measure included in

\footnotetext{
${ }^{4}$ This vector includes the number of years of schooling, labor market experience and its square, employer tenure and its square, and dummies for gender, race, industry, occupation, region and health status. Also included is a dummy indicator for increase in responsibilities.

${ }^{5}$ In the fixed-effects specifications, all variables are measured in deviation form individual means. Thus, the (fixed) unobserved individual productivity component $\alpha_{i}$ drops out of equation (5).
} 
the NLSY data is more like another form of piece rate for which workers get rewarded if they surpass a quantitative target, then this strategic interaction should also be at work. ${ }^{6}$ If, instead, bonuses reported in this data set are more akin to merit pay, then no such strategic interaction is at play. Although I do not have the actual rates paid to these workers and hence cannot directly see whether these rates are high early in the employment relationship only to be cut later, one can get an idea of such strategic behavior by interacting the incentive pay dummies with employer tenure. According to Lazear, if rates are set higher early in the employment relationship, then the measured effect of being paid a piece rate (and, possibly, bonuses) should be a negative function of tenure. We should thus expect a negative sign for the interaction term.

Results are reported in Table 7. Consistent with prior evidence, we can see in column 1 that OLS estimates indicate that piece rate workers and bonus workers earn higher average wages compared with workers paid on hourly basis or paid salaries. Interestingly, once fixed-effects are used, the positive correlation between the use of a piece rate and wages is basically unaffected, while the effect of being paid a bonus vanishes completely. These results suggest that piece rates seem to act as an incentive device while the same cannot be said for bonuses. In the latter case, the positive impact measured with OLS merely seems to reflect omitted ability variable bias. Thus controlling for unobserved worker productivity, there is no evidence that workers paid bonuses earn a premium over those on an hourly or salary pay scheme. This is consistent with MacLeod and Malcomson (1989)'s story of how labor market conditions affect the form of the contract (i.e. base pay plus a bonus vs. straight salary) while the total amount paid to workers remains the same. Of course, one has to keep in mind that this explanation rests on interpreting the results as evidence that the bonus measure included in the data is in fact a merit pay scheme.

Turning my attention to the possibility of strategic behavior between workers paid piece rates and their employers (i.e. the ratchet effect), columns 3 and 4 of Table 7 show the results of including interaction terms between tenure and the incentive pay dummies. We can see that for piece rate workers, the effect of on wages seem to decline with tenure with the employer. Even with fixed-effects, the interaction term is still significant at the $10 \%$ level. ${ }^{7}$ In the case of workers paid bonuses, there is

\footnotetext{
${ }^{6}$ See Oyer (1995) for an analysis of the interaction between incentives and sales seasonality.

${ }^{7}$ Given that the estimated coefficient is significant at the $10 \%$ level, one prudent explanation would be to acknowledge the possibility of some selection effect going on. More precisely, it is possible that the negative effect of the interaction term
} 
no evidence of a negative relationship between tenure and the occurrence of bonuses, either with OLS or with fixed-effects.

\subsection{Methods of Pay and Wage Dispersion}

The closer link between productivity and pay that is a characteristic of piece rate contracts should be reflected in the fact that most of the unexplained variance resulting from the estimation of equation (5) can be attributed to the variance of unobserved worker productivity in the case of piece rate workers. The first step to verifying this prediction is to break the sample into three distinct subsamples according to the method of pay (piece rate, bonus, others). Then, exploiting again the longitudinal aspect of the data set, I use the log wage observations adjusted for schooling and labor market experience to estimate a simple model of the covariance structure of wages for each type of pay methods using Chamberlain's $(1982,1984)$ minimum distance estimator adapted to unbalanced data ${ }^{8}$. In other words, the approach used is first to regress (by year) the log wage on labor market experience and schooling and then to use the estimated residuals to compute estimates of the unrestricted covariance matrix of residuals. I then impose the restrictions implied by the simple error component structure given in equation (5) to estimate the parameters of interest and to test the fit of the model. ${ }^{9}$

Let $\mathrm{e}_{i t}$ be the residual from a first-stage regression of the log-wage on schooling and labor market experience, then we have:

$$
e_{i t}=\ln w_{i t}-X_{i t}^{\prime} \widehat{\gamma}
$$

where $X_{i t}^{\prime}$ is the vector of controls (experience and schooling) and $\widehat{\gamma}$ is the vector of the estimated parameters. Then a natural estimator of the covariance between the residuals at time $t$ and at time $s$ is given by

$$
\widehat{\sigma_{t, s}}=\frac{1}{N} \sum_{i=1}^{N} e_{i t} e_{i s}
$$

estimated with OLS reflects in part the fact good workers who perform very well move to another employer when their current employer attempts to cut their rate. Outside options for these workers thus prevents the ratchet effect from taking place (see Kanemoto and MacLeod (1992) on that point).

${ }^{8}$ See Abowd and Card (1989) and Farber and Gibbons (1996)for applications of these techniques.

${ }^{9}$ Note that the results are not sensitive to different specifications of the log wage equation estimated in the first step. Various specifications including controls for tenure, occupation and industry were used without altering the basic conclusions. 
where $\mathrm{N}$ represents the number of workers. ${ }^{10} \mathrm{~A}$ consistent estimator for the standard error of $\widehat{\sigma_{t, s}}$ is then given by

$$
\operatorname{Std}\left(\widehat{\sigma_{t, s}}\right)=\sqrt{\frac{1}{N} \sum_{i=1}^{N}\left(e_{i t} e_{i s}-\widehat{\sigma_{t, s}}\right)^{2}}
$$

Table 8 shows estimates of the empirical covariance matrices by method of pay along with their appropriate standard errors and the number of workers whose residuals were used in the computations. Turning now to the restrictions imposed by the error component structure suggested by equation (5), I assume that the observed residual is given by

$$
e_{i t}=\alpha_{i}+\epsilon_{i t}
$$

Therefore, the variance of the observed residuals at period $t$ is

$$
\operatorname{var}\left(e_{i t}\right)=E\left(\alpha_{i}\right)^{2}+E\left(\epsilon_{i t}\right)^{2}=\sigma_{\alpha}^{2}+\sigma_{\epsilon}^{2}
$$

and the covariance between residuals at periods $\mathrm{t}$ and $\mathrm{s}$ is

$$
\operatorname{cov}\left(e_{i t} e_{i s}\right)=E\left(\alpha_{i}\right)^{2}+E\left(\epsilon_{i t} \epsilon_{i s}\right)=\sigma_{\alpha}^{2}
$$

since I am assuming that $\epsilon$ is i.i.d. Thus, the model to be estimated has the following linear structure

$$
\sigma_{t s}=\theta_{1}+\theta_{2} D_{t s}
$$

where $D_{t s}=1$ if $\mathrm{t}=\mathrm{s}$ and $D_{t s}=0$ otherwise while $\theta_{1}=\sigma_{\alpha}^{2}$ and $\theta_{2}=\sigma_{\epsilon}^{2}$. Now consider the covariance matrices shown in Table 8 . With 3 years of data, that means I have 6 distinct elements (per method of pay) that I try to fit with the two component of variance representation given by equations (10) and (11). The covariance model given by these two equations imposes that all diagonal elements should be equal and that all off-diagonal elements should also be equal. This gives a total of four restrictions to be imposed on the data. To test these restrictions, I make use of the minimum distance estimator proposed by Chamberlain. Succinctly, let $\mathrm{m}_{i}$ be the column vector of the unique elements of the $3 \mathrm{X} 3$ cross-product matrix of residuals for workers i. Then I calculate, for each method of pay, the sample means of the elements of $\mathrm{m}_{i}$, giving us the column vector $\mathrm{m}$. The model I want to estimate is a model for

\footnotetext{
${ }^{10}$ Note that the data being unbalanced, the number of workers used to compute the estimate is not the same for each covariance elements. To simplify the exposition of the methodology, 1 assume that the data are balanced.
} 
m. A consistent estimator of the covariance matrix of the covariance elements in $\mathrm{m}$ is given by

$$
\Omega=\frac{1}{N} \sum_{i=1}^{N}\left(m_{i}-m\right)\left(m_{i}-m\right)^{\prime}
$$

The equally weighted minimum distance estimator (EWMD) minimizes the following quadratic form with respect to $\Theta$

$$
\Pi=[m-D \Theta]^{\prime}[m-D \Theta]
$$

where $\mathrm{D}$ is the design matrix made of ones and zeros while $\Theta=\left(\sigma_{\alpha}^{2}, \sigma_{\epsilon}^{2}\right)$ is the vector of parameters to be estimated. On the other hand, the optimally weighted minimum distance estimator (OMD) minimizes with respect to $\Theta$ the quadratic form

$$
\Pi=[m-D \Theta]^{\prime} \Omega^{-1}[m-D \Theta]
$$

Altonji and Segal (1994) discuss how small sample size can lead to a substantial bias when using the OMD estimator in comparison to using the identity matrix as the weighting matrix. Results are thus presented for both estimators. Under the null hypothesis of a correct specification in equation (12), the value of the objective function (14) (or (15)) is distributed as a $\chi^{2}$ with degrees of freedom given by the number of restrictions (the difference between the number of sample moments to fit (6) and the number of parameters (2). Results in Table 9 show that the simple two component model fits the data quite well as all goodness-of-fit statistics are not surprising values coming from a $\chi^{2}(4)$ distribution. ${ }^{11}$ As for the estimated parameters, note that the relative contribution of unobserved worker productivity is much larger in the case of workers being paid a piece rate. This is consistent with the view that pay and productivity are more closely linked for these workers than is the case for other workers. Thus, although the simple self-selection story of workers into piece rate jobs does not get much support from the data, the prediction of Lazear's (1986) model concerning the dispersion of wages for incentive workers is strongly supported. Note also that since controlling for unobserved ability accounts for a sizeable portion of the variance, Seiler's (1984) story that piece rate workers get rewarded for facing higher income risks is not consistent with the results reported here.

\footnotetext{
${ }^{11}$ This is not really a surprise given the low number of sample moments to fit. When the time dimension in the data set increases, similar exercises at trying to fit such a parsimonious structure (e.g. Abowd and Card (1989)) usually reject it quite decidedly.
} 


\section{Conclusion}

There are two important caveats to the results presented in this paper. The first one is that we should keep in mind the limitations imposed by the data on methods of pay contained in the NLSY. We do not have the dollar amounts paid according to "incentive" pay. Thus, it may be that for many workers, much of their labor income is in the form of hourly rates or salaries supplemented with a certain amount of income earned through pay-for-performance schemes. The second caveat is that I have abstracted from unobserved job-match characteristics. Although not shown here, the estimation of a within job fixed-effect model proved to be problematic in that much of the variance needed to estimate the coefficients was eliminated thereby blowing up the standard errors, making all inferences rather weak concerning the effect of piece rates on earnings. The main reason is that pay methods do not appear to change much for workers during their tenure with the employer. For example, in the case of piece rate workers, when I consider only those who stay three years with the same employer, the simple correlation coefficient between the piece rate dummy indicator and its lagged value is $98 \%$. It is the cross-employer variation that allows identification of the effects. Better data will be required to deal in a satisfactory manner with the issue of unobserved job-match characteristics. 


\section{References}

[1] J.M. Abowd and D. Card. On the Covariance structure of earnings and hour changes. Econometrica, LVII:411-445, 1989.

[2] J.G. Altonji and L.M. Segal. Small sample bias in gmm estimation of covariance structures. NBER Technical Working Paper No. 156, 1994.

[3] G. Baker, R. Gibbons, and K.J. Murphy. Subjective performance measures in optimal incentive contracts. The Quarterly Journal of Economics, 109(439):1125-1156, November 1994.

[4] G.P. Baker, M. Gibbs, and B. Holström. The wage policy of a firm. The Quarterly Journal of Economics, 109(439):921-955, November $1994 \mathrm{~A}$.

[5] G.P. Baker, M. Gibbs, and B. Holström. The internal economics of the firm: Evidence from personnel data. The Quarterly Journal of Economics, 109(439):881-920, November 1994A.

[6] George P. Baker, Michael C. Jensen, and Kevin J. Murphy. Compensation and incentives: Practice vs. theory. Journal of Fiannce, 43(3):593-616, July 1988.

[7] C. Brown. Firm's choice of method of pay. Industrial and Labour Relations Review, 43(3):165-182, 1990.

[8] C. Brown. Wage levels and methods of pay. Rand Journal of Economics, 23:366-375, 1992.

[9] G. Chamberlain. Multivariate regression models for panel data. Journal of Econometrics, XVIII:5-46, 1982.

[10] G. Chamberlain. Panel data. In Zvi Griliches and Michael D. Intriligator, editors, Handbook of Econometrics, volume II, chapter 22, pages 1247-1318. Amsterdam: North-Holland, 1984.

[11] P. Doeringer and M. Piore. Internal Labor Markets and Manpower Analysis. Lexington Books, Lexington, MA, USA, 1971.

[12] B.T. Ewing. Wages and performance-based pay: Evidence from the NLSY. Economics Letters, 51:241-246, 1996.

[13] H.S. Farber and R. Gibbons. Learning and wage dynamics. Quarterly Journal of Economics, CXI:1007-1047, 1996. 
[14] R. Gibbons and K. Murphy. Optimal incentive contracts in the presence of career concerns: Theory and evidence. Journal of Political Economy, 100:468-505, 1992.

[15] M. Jensen and K.J. Murphy. Performance pay and top management incentives. Journal of Political Economy, 98:225-264, 1990.

[16] Y. Kanemoto and W.B. MacLeod. The ratchet effect and the market for secondhand workers. Journal of Labor Economics, pages 85-98, 1991.

[17] E.P. Lazear. Salaries and piece rates. Journal of Business, 59:405431, 1986.

[18] W.B. MacLeod and J.M. Malcolmson. Implicit contracts, incentive compatibility, and involuntary unemployment. Econometrica, 57(2):447-480, March 1989.

[19] P. Oyer. The effect of sales incentives on business seasonality. September 1995. mimeo. Princeton University.

[20] J. Pencavel. Work effort, on the job screening, and alternative methods of ermuneration. In R.G. Ehrenberg, editor, Research in Labor Economics, volume 1. Greenwich, Conn: JAI Press, 1977.

[21] E. Seiler. Piece rates vs time rates: The effect of incentives on earnings. Review of Economics and Statistics, 66:363-376, 1984. 
Table 1

Mean Sample Statistics

\begin{tabular}{lc}
\hline Hourly Earnings (\$1979) & 7.1 \\
Schooling & 12.4 \\
Percentage Female & 43.7 \\
Percentage Paid Piece rates & 9.4 \\
Percentage Paid Bonuses & 14.1 \\
Sample Size & 8165 \\
Number of Workers & 3847 \\
\hline
\end{tabular}


Table 2

Number of Observations by Industry and Occupation (1-digit)-NLSY Total Sample

\begin{tabular}{|c|c|c|c|c|c|c|c|c|c|c|}
\hline & $\begin{array}{r}\text { Prof., Tech., } \\
\& \text { Kindred } \\
\end{array}$ & $\begin{array}{r}\text { Manag. \& } \\
\text { Admin. } \\
\end{array}$ & Sales & $\begin{array}{r}\text { Clerical \& } \\
\text { Kindred } \\
\end{array}$ & $\begin{array}{l}\text { Craftsmen } \\
\& \text { Kindred } \\
\end{array}$ & $\begin{array}{l}\text { Operatives } \\
\& \text { Kindred } \\
\end{array}$ & Laborers & $\begin{array}{r}\text { Service } \\
\text { Workers } \\
\end{array}$ & Total & Percentages \\
\hline $\begin{array}{l}\text { Agricuture, Forestry, } \\
\text { \& Fisheries }\end{array}$ & 6 & 4 & 1 & 3 & 15 & 8 & 48 & 1 & 86 & $1.05 \%$ \\
\hline Mining & 16 & 4 & 0 & 9 & 14 & 40 & 5 & 0 & 88 & $1.08 \%$ \\
\hline Construction & 7 & 34 & 4 & 27 & 374 & 98 & 145 & 1 & 690 & $8.45 \%$ \\
\hline Manufacturing & 219 & 146 & 60 & 273 & 374 & 956 & 120 & 36 & 2184 & $26.75 \%$ \\
\hline $\begin{array}{l}\text { Transportation, } \\
\text { Communications, \& } \\
\text { Other Public Utilities }\end{array}$ & 66 & 62 & 17 & 130 & 105 & 150 & 49 & 24 & 603 & $7.39 \%$ \\
\hline $\begin{array}{l}\text { Wholesale and } \\
\text { Retail Trade }\end{array}$ & 43 & 459 & 185 & 381 & 132 & 199 & 107 & 335 & 1841 & $22.55 \%$ \\
\hline $\begin{array}{l}\text { Finance, Insurance, } \\
\text { and Real Estate }\end{array}$ & 41 & 123 & 88 & 316 & 7 & 2 & 8 & 30 & 615 & $7.53 \%$ \\
\hline Services & 512 & 194 & 39 & 460 & 158 & 123 & 50 & 522 & 2058 & $25.21 \%$ \\
\hline Totals & 910 & 1026 & 394 & 1599 & 1179 & 1576 & 532 & 949 & 8165 & \\
\hline Percentages & $11.15 \%$ & $12.57 \%$ & $4.83 \%$ & $19.58 \%$ & $14.44 \%$ & $19.30 \%$ & $6.52 \%$ & $11.62 \%$ & & \\
\hline
\end{tabular}


Table 3

Number of Observations by Industry and Occupation (1-digit)-NLSY Piece Rate Subsample

\begin{tabular}{|c|c|c|c|c|c|c|c|c|c|c|}
\hline & $\begin{array}{l}\text { Prof., Tech., } \\
\& \text { Kindred } \\
\end{array}$ & $\begin{array}{r}\text { Manag. \& } \\
\text { Admin. }\end{array}$ & Sales & $\begin{array}{r}\text { Clerical \& } \\
\text { Kindred } \\
\end{array}$ & $\begin{array}{l}\text { Craftsmen } \\
\& \text { Kindred } \\
\end{array}$ & $\begin{array}{l}\text { Operatives } \\
\& \text { Kindred } \\
\end{array}$ & Laborers & $\begin{array}{r}\text { Service } \\
\text { Workers } \\
\end{array}$ & Total & Percentages \\
\hline $\begin{array}{l}\text { Agricuture, Forestry, } \\
\text { \& Fisheries }\end{array}$ & 0 & 0 & 1 & 0 & 2 & 1 & 3 & 0 & 7 & $0.91 \%$ \\
\hline Mining & 0 & 0 & 0 & 0 & 0 & 0 & 0 & 0 & 0 & $0.00 \%$ \\
\hline Construction & 1 & 3 & 1 & 0 & 21 & 10 & 6 & 0 & 42 & $5.48 \%$ \\
\hline Manufacturing & 6 & 15 & 26 & 3 & 22 & 153 & 10 & 1 & 236 & $30.81 \%$ \\
\hline $\begin{array}{l}\text { Transportation, } \\
\text { Communications, \& } \\
\text { Other Public Utilities }\end{array}$ & 3 & 3 & 5 & 6 & 2 & 21 & 6 & 0 & 46 & $6.01 \%$ \\
\hline $\begin{array}{l}\text { Wholesale and } \\
\text { Retail Trade }\end{array}$ & 7 & 59 & 72 & 15 & 27 & 21 & 9 & 6 & 216 & $28.20 \%$ \\
\hline $\begin{array}{l}\text { Finance, Insurance, } \\
\text { and Real Estate }\end{array}$ & 2 & 13 & 34 & 16 & 0 & 1 & 1 & 0 & 67 & $8.75 \%$ \\
\hline Services & 13 & 14 & 13 & 14 & 36 & 12 & 6 & 44 & 152 & $19.84 \%$ \\
\hline Totals & 32 & 107 & 152 & 54 & 110 & 219 & 41 & 51 & 766 & \\
\hline Percentages & $4.18 \%$ & $13.97 \%$ & $19.84 \%$ & $7.05 \%$ & $14.36 \%$ & $28.59 \%$ & $5.35 \%$ & $6.66 \%$ & & \\
\hline
\end{tabular}


Table 4

Number of Observations by Industry and Occupation (1-digit)-NLSY Bonus Subsample

\begin{tabular}{|c|c|c|c|c|c|c|c|c|c|c|}
\hline & $\begin{array}{l}\text { Prof., Tech., } \\
\text { \& Kindred } \\
\end{array}$ & $\begin{array}{r}\text { Manag. \& } \\
\text { Admin. }\end{array}$ & Sales & $\begin{array}{r}\text { Clerical \& } \\
\text { Kindred } \\
\end{array}$ & $\begin{array}{l}\text { Craftsmen } \\
\& \text { Kindred } \\
\end{array}$ & $\begin{array}{l}\text { Operatives } \\
\text { \& Kindred } \\
\end{array}$ & Laborers & $\begin{array}{r}\text { Service } \\
\text { Workers } \\
\end{array}$ & Total & Percentages \\
\hline $\begin{array}{l}\text { Agricuture, Forestry, } \\
\text { \& Fisheries }\end{array}$ & 0 & 0 & 1 & 0 & 2 & 1 & 5 & 0 & 9 & $0.78 \%$ \\
\hline Mining & 3 & 2 & 0 & 2 & 1 & 8 & 0 & 0 & 16 & $1.39 \%$ \\
\hline Construction & 1 & 12 & 0 & 2 & 25 & 8 & 10 & 0 & 58 & $5.03 \%$ \\
\hline Manufacturing & 29 & 37 & 22 & 27 & 47 & 93 & 14 & 2 & 271 & $23.48 \%$ \\
\hline $\begin{array}{l}\text { Transportation, } \\
\text { Communications, \& } \\
\text { Other Public Utilities }\end{array}$ & 15 & 12 & 6 & 18 & 12 & 27 & 6 & 0 & 96 & $8.32 \%$ \\
\hline $\begin{array}{l}\text { Wholesale and } \\
\text { Retail Trade }\end{array}$ & 10 & 152 & 34 & 36 & 15 & 22 & 15 & 25 & 309 & $26.78 \%$ \\
\hline $\begin{array}{l}\text { Finance, Insurance, } \\
\text { and Real Estate }\end{array}$ & 8 & 26 & 23 & 48 & 0 & 1 & 0 & 2 & 108 & $9.36 \%$ \\
\hline Services & 69 & 51 & 15 & 61 & 19 & 20 & 5 & 47 & 287 & $24.87 \%$ \\
\hline Totals & 135 & 292 & 101 & 194 & 121 & 180 & 55 & 76 & 1154 & \\
\hline Percentages & $11.70 \%$ & $25.30 \%$ & $8.75 \%$ & $16.81 \%$ & $10.49 \%$ & $15.60 \%$ & $4.77 \%$ & $6.59 \%$ & & \\
\hline
\end{tabular}


Table 5

Number of Observations by Industry and Occupation (1-digit)-NLSY Promotion Subsample

\begin{tabular}{|c|c|c|c|c|c|c|c|c|c|c|}
\hline & $\begin{array}{r}\text { Prof., Tech., } \\
\text { \& Kindred }\end{array}$ & $\begin{array}{r}\text { Manag. \& } \\
\text { Admin. }\end{array}$ & Sales & $\begin{array}{r}\text { Clerical \& } \\
\text { Kindred } \\
\end{array}$ & $\begin{array}{l}\text { Craftsmen } \\
\text { \& Kindred }\end{array}$ & $\begin{array}{l}\text { Operatives } \\
\& \text { Kindred }\end{array}$ & Laborers & $\begin{array}{r}\text { Service } \\
\text { Workers }\end{array}$ & Total & Percentages \\
\hline $\begin{array}{l}\text { Agricuture, Forestry, } \\
\& \text { Fisheries }\end{array}$ & 1 & 0 & 0 & 0 & 4 & 1 & 8 & 0 & 14 & $1.00 \%$ \\
\hline Mining & 2 & 1 & 0 & 2 & 0 & 5 & 2 & 0 & 12 & $0.85 \%$ \\
\hline Construction & 1 & 10 & 1 & 8 & 61 & 11 & 18 & 1 & 111 & $7.91 \%$ \\
\hline Manufacturing & 48 & 45 & 14 & 60 & 76 & 105 & 15 & 8 & 371 & $26.42 \%$ \\
\hline $\begin{array}{l}\text { Transportation, } \\
\text { Communications, \& } \\
\text { Other Public Utilities }\end{array}$ & 12 & 13 & 2 & 24 & 17 & 19 & 8 & 1 & 96 & $6.84 \%$ \\
\hline $\begin{array}{l}\text { Wholesale and } \\
\text { Retail Trade }\end{array}$ & 5 & 140 & 31 & 69 & 26 & 21 & 18 & 38 & 348 & $24.79 \%$ \\
\hline $\begin{array}{l}\text { Finance, Insurance, } \\
\text { and Real Estate }\end{array}$ & 9 & 30 & 12 & 55 & 2 & 1 & 2 & 3 & 114 & $8.12 \%$ \\
\hline Services & 92 & 49 & 9 & 77 & 24 & 13 & 9 & 65 & 338 & $24.07 \%$ \\
\hline Totals & 170 & 288 & 69 & 295 & 210 & 176 & 80 & 116 & 1404 & \\
\hline Percentages & $12.11 \%$ & $20.51 \%$ & $4.91 \%$ & $21.01 \%$ & $14.96 \%$ & $12.54 \%$ & $5.70 \%$ & $8.26 \%$ & & \\
\hline
\end{tabular}


Table 6

Number of Observations by Industry and Occupation (1-digit)-NLSYIncrease in Responsibility Subsample

\begin{tabular}{|c|c|c|c|c|c|c|c|c|c|c|}
\hline & $\begin{array}{r}\text { Prof., Tech., } \\
\text { \& Kindred }\end{array}$ & $\begin{array}{r}\text { Manag. \& } \\
\text { Admin. }\end{array}$ & Sales & $\begin{array}{r}\text { Clerical \& } \\
\text { Kindred } \\
\end{array}$ & $\begin{array}{l}\text { Craftsmen } \\
\text { \& Kindred }\end{array}$ & $\begin{array}{l}\text { Operatives } \\
\& \text { Kindred }\end{array}$ & Laborers & $\begin{array}{r}\text { Service } \\
\text { Workers }\end{array}$ & Total & Percentages \\
\hline $\begin{array}{l}\text { Agricuture, Forestry, } \\
\& \text { Fisheries }\end{array}$ & 1 & 1 & 0 & 0 & 5 & 1 & 10 & 0 & 18 & $0.79 \%$ \\
\hline Mining & 3 & 2 & 0 & 3 & 2 & 6 & 2 & 0 & 18 & $0.79 \%$ \\
\hline Construction & 2 & 11 & 1 & 12 & 95 & 20 & 31 & 0 & 172 & $7.56 \%$ \\
\hline Manufacturing & 77 & 61 & 22 & 95 & 121 & 197 & 23 & 12 & 608 & $26.74 \%$ \\
\hline $\begin{array}{l}\text { Transportation, } \\
\text { Communications, \& } \\
\text { Other Public Utilities }\end{array}$ & 19 & 19 & 2 & 46 & 33 & 28 & 13 & 4 & 164 & $7.21 \%$ \\
\hline $\begin{array}{l}\text { Wholesale and } \\
\text { Retail Trade }\end{array}$ & 18 & 180 & 49 & 107 & 37 & 49 & 24 & 63 & 527 & $23.18 \%$ \\
\hline $\begin{array}{l}\text { Finance, Insurance, } \\
\text { and Real Estate }\end{array}$ & 13 & 46 & 28 & 91 & 4 & 2 & 1 & 6 & 191 & $8.40 \%$ \\
\hline Services & 148 & 61 & 12 & 147 & 44 & 27 & 17 & 120 & 576 & $25.33 \%$ \\
\hline Totals & 281 & 381 & 114 & 501 & 341 & 330 & 121 & 205 & 2274 & \\
\hline Percentages & $12.36 \%$ & $16.75 \%$ & $5.01 \%$ & $22.03 \%$ & $15.00 \%$ & $14.51 \%$ & $5.32 \%$ & $9.01 \%$ & & \\
\hline
\end{tabular}


Table 7

Earnings Function Estimates

(Dependent Variable: Log of Real Hourly Labor Income)

\begin{tabular}{|c|c|c|c|c|}
\hline \multirow[b]{2}{*}{ Independent Variables } & \multicolumn{4}{|c|}{ Specifications } \\
\hline & $\begin{array}{c}1 \\
(\mathrm{OLS})\end{array}$ & $\begin{array}{c}2 \\
\text { (Fixed-Effects) }\end{array}$ & $\begin{array}{c}3 \\
(\mathrm{OLS})\end{array}$ & $\begin{array}{c}4 \\
\text { (Fixed-Effects) }\end{array}$ \\
\hline Piece Rate & $\begin{array}{r}0.0491 \\
(0.0171)\end{array}$ & $\begin{array}{r}0.0469 \\
(0.0238)\end{array}$ & $\begin{array}{r}0.0957 \\
(0.0248)\end{array}$ & $\begin{array}{r}0.0859 \\
(0.0332)\end{array}$ \\
\hline Piece Rate X Tenure & - & - & $\begin{array}{r}-0.0159 \\
(0.0061)\end{array}$ & $\begin{array}{r}-0.0141 \\
(0.0082)\end{array}$ \\
\hline Bonus & $\begin{array}{r}0.0679 \\
(0.0141)\end{array}$ & $\begin{array}{r}-0.0019 \\
(0.0173)\end{array}$ & $\begin{array}{r}0.0607 \\
(0.0213)\end{array}$ & $\begin{array}{r}-0.0313 \\
(0.0261)\end{array}$ \\
\hline Bonus X Tenure & - & - & $\begin{array}{r}0.0003 \\
(0.0049)\end{array}$ & $\begin{array}{r}0.0089 \\
(0.0060)\end{array}$ \\
\hline R-Squared & 0.3468 & 0.7988 & 0.3473 & 0.7999 \\
\hline
\end{tabular}

Notes. Sample size: 8,165 . Other covariates include the number of years of schooling, labor market experience and its square, employer tenure and its square, and dummies for gender, race, industry, occupation, region, health status and increase in responsibilities. 
Table 8

Empirical Covariance Matrices of Log Wage Residuals

(Standard Deviations in parentheses)

[Cell Size]

A. Workers Paid Salaries or Hourly Rates $(\#=3390)$

$1988 \quad 1989 \quad 1990$

$\begin{array}{rrrr}1988 & 0.2249 & & \\ & (0.0269) & & \\ & {[2062]} & & \\ 1989 & 0.1122 & 0.2295 & \\ & (0.0061) & (0.0259) & \\ & {[1374]} & {[2235]} & \\ 1990 & 0.1023 & 0.1184 & 0.2432 \\ & (0.0064) & (0.0059) & (0.0275) \\ & {[1200]} & {[1420]} & {[2136]}\end{array}$

B. Workers Paid Piece Rates (\# = 533)

$1988 \quad 1989 \quad 1990$

$\begin{array}{rrrr}1988 & 0.2335 & & \\ & (0.0294) & & \\ & {[255]} & & \\ 1989 & 0.2287 & 0.3248 & \\ & (0.0382) & (0.0671) & \\ & {[100]} & {[248]} & \\ 1990 & 0.2109 & 0.1785 & 0.3258 \\ & (0.0382) & (0.0292) & (0.0734) \\ & {[83]} & {[107]} & {[263]}\end{array}$


Table 8 - continued

Empirical Covariance Matrices of Log Wage Residuals

(Standard Deviations in parentheses)

[Cell Size]

\begin{tabular}{lrrr}
\hline C. Workers Paid Bonuses $(\#=718)$ & & & \\
& & & \\
& & & \\
& & & \\
1988 & 0.1878 & & \\
& $(0.0243)$ & & \\
& {$[376]$} & & \\
1989 & 0.1144 & 0.2152 & \\
& $(0.0174)$ & $(0.0456)$ & \\
& {$[130]$} & {$[391]$} & \\
& 0.1129 & 0.1296 & 0.1645 \\
& $(0.0172)$ & $(0.0180)$ & $(0.0135)$ \\
& {$[117]$} & {$[137]$} & {$[387]$} \\
\hline
\end{tabular}

Notes. The wage observations used to compute these covariances are adjusted for education and experience in the labor market. The total number of workers in Panels A, B, and C is greater than the total number of workers in the overall sample because many workers experience different pay methods. 
Table 9

Minimum Distance Estimation of Covariance Structure (Standard Errors in parentheses)

A. Equally Weighted Minimum Distance Estimation

\begin{tabular}{lrrr} 
& $\begin{array}{r}\text { Salaried and Hourly } \\
\text { Paid Workers }\end{array}$ & $\begin{array}{r}\text { Piece Rate } \\
\text { Workers }\end{array}$ & $\begin{array}{r}\text { Bonus } \\
\text { Workers }\end{array}$ \\
\hline$\underline{\text { Parameter }}$ & & & \\
Variance of Unobserved & 0.1109 & 0.2061 & 0.1024 \\
Worker Ability & $(0.0051)$ & $(0.0240)$ & $(0.0087)$ \\
Variance of i.i.d & 0.1216 & 0.0886 & 0.1074 \\
Component & $(0.0072)$ & $(0.0339)$ & $(0.0124)$ \\
Chi-Square Statistic & 1.05 & 3.68 & 0.66 \\
Degrees of Freedom & 4 & 4 & 4 \\
Number of Workers & 3390 & 533 & 718 \\
\hline
\end{tabular}

B. Optimally Weighted Minimum Distance Estimation

\begin{tabular}{rrr}
$\begin{array}{r}\text { Salaried and Hourly } \\
\text { Paid Workers }\end{array}$ & $\begin{array}{r}\text { Piece Rate } \\
\text { Workers }\end{array}$ & $\begin{array}{r}\text { Bonus } \\
\text { Workers }\end{array}$ \\
\hline
\end{tabular}

Parameter

Variance of Unobserved

$\begin{array}{rrr}0.1116 & 0.1821 & 0.1036 \\ (0.0065) & (0.0392) & (0.0078)\end{array}$

Worker Ability $\begin{array}{lll}(0.0065) & (0.0392) & (0.0078)\end{array}$

Variance of i.i.d

Component

$\begin{array}{lll}0.1109 & 0.0505 & 0.1029\end{array}$

$\begin{array}{lll}(0.0206) & (0.0391) & (0.0189)\end{array}$

Chi-Square Statistic

7.15

8.22

2.38

Degrees of Freedom

$4 \quad 4$

4

Number of Workers

3390

533 


\section{Liste des publications au CIRANO .}

\section{Cahiers CIRANO / CIRANO Papers (ISSN 1198-8169)}

96c-1 Peut-on créer des emplois en réglementant le temps de travail ? / par Robert Lacroix

95c-2 Anomalies de marché et sélection des titres au Canada / par Richard Guay, JeanFrançois L'Her et Jean-Marc Suret

95c-1 La réglementation incitative / par Marcel Boyer

94c-3 L'importance relative des gouvernements : causes, conséquences et organisations alternative / par Claude Montmarquette

94c-2 Commercial Bankruptcy and Financial Reorganization in Canada / par Jocelyn Martel

94c-1 Faire ou faire faire : La perspective de l'économie des organisations / par Michel Patry

\section{Série Scientifique / Scientific Series (ISSN 1198-8177)}

97s-15 Liberalization, Political Risk and Stock Market Returns in Emerging Markets / Jean-Marc Suret, Jean-François L'Her

97s-14 Methods of Pay and Earnings: A Longitudinal Analysis / Daniel Parent

97s-13 A Note on Hedging in ARCH and Stochastic Volatility Option Pricing Models / René Garcia et Éric Renault

97s-12 Equilibrium Asset Prices and No-Arbitrage with Portfolio Constraints / Jérôme B. Detemple et Shashidhar Murthy

97s-11 Aggregation, Efficiency and Mutual Fund Separation in Incomplete Markets / Jérôme B. Detemple et Piero Gottardi

97s-10 Global Strategic Benchmarking, Critical Capabilities and Performance of Aerospace Subcontractors / Élisabeth Lefebvre, Louis A. Lefebvre

97s-09 Reported Job Satisfaction: What Does It Mean? / Louis Lévy-Garboua, Claude Montmarquette

97s-08 Living on a Noisy and Dusty Street: Implications for Environmental Evaluation / Tagreed Boules, Robert Gagné et Paul Lanoie

97s-07 The Location of Comparative Advantages on the Basis of Fundamentals Only / Thijs ten Raa et Pierre Mohnen

97s-06 GARCH for Irregularly Spaced Financial Data: The ACD-GARCH Model / Eric Ghysels, Joanna Jasiak

97s-05 Can Capital Markets Create Incentives for Pollution Control? / Paul Lanoie, Benoît Laplante et Maité Roy

97s-04 La régie des services informatiques : Le rôle de la mesure et des compétences dans les décisions d'impartition / Benoit A. Aubert, Suzanne Rivard et Michel Patry

97s-03 Competition and Access in Telecoms: ECPR, Global Price Caps, and Auctions / Marcel Boyer

* Vous pouvez consulter la liste complète des publications du CIRANO et les publications elles-mêmes sur notre site World Wide Web à l'adresse suivante :

http://www.cirano.umontreal.ca/publication/page1.htm 